Article

\title{
Improvement in Weldment of Dissimilar 9\% CR Heat-Resistant Steels by Post-Weld Heat Treatment
}

\author{
Jiankun Xiong ${ }^{1,2, *}$, Ting $\mathrm{Li}^{3}$, Xinjian Yuan ${ }^{1,3, *}$, Guijun Mao ${ }^{2}$, Jianping Yang ${ }^{2}$, Lin Yang ${ }^{2}$ and \\ Jian $\mathrm{Xu}^{2}$ \\ 1 State Key Laboratory of Long-life High Temperature Materials, Dongfang Turbine Co., Ltd., \\ Deyang 618000, China \\ 2 Manufacturing Technology Department, Dongfang Turbine Co., Ltd., Deyang 618000, China; \\ 2008jiaefu@163.com (G.M.); yangjianping66@163.com (J.Y.); dtcyanglin@dongfang.com (L.Y.); \\ xujianlut@163.com (J.X.) \\ 3 College of Materials Science and Engineering, Chongqing University, No. 174, Shazheng Street, \\ Shapingba District, Chongqing 400044, China; liting000@cqu.edu.cn \\ * Correspondence: xiongkai2010@163.com (J.X.); xinjianyuan@yahoo.com (X.Y.); Tel.: +86-23-6512-7306 (X.Y.)
}

Received: 6 September 2020; Accepted: 24 September 2020; Published: 2 October 2020

\begin{abstract}
The effect of the post-weld heat treatment on the microstructures and mechanical properties of the dissimilar joint of G115, a novel developed martensite heat resistant steel, and CB2 steel, currently used in an ultra-super-critical power unit, was investigated. The results indicate that the quenched martensite underwent decomposition and transformation, and the amount of dislocations were sharply decreased in the weld metal after post-weld heat treatment (PWHT). Many nano-scale $\mathrm{M}_{23} \mathrm{C}_{6}$ precipitates present in the weldment were distributed on the grain and grain boundary in a dispersed manner with PWHT. The average microhardness of the weldment decreased from about $400 \mathrm{HV}$ to 265-290 HV after PWHT and only a slight decrease in the microhardness of CB2 steel was detected after PWHT at $760{ }^{\circ} \mathrm{C}$. In contrast to the case of the as-received joint, the tensile strength of the joint was improved from $630 \mathrm{MPa}$ to $694 \mathrm{MPa}$ and the fracture location moved from the weld metal to the base metal after PWHT. The fracture surface consisted of a cleavage fracture mode without PWHT, whereas many dimples were observed on the fracture surface with PWHT.
\end{abstract}

Keywords: heat resistant steels; welding; post-weld heat treatment; microstructure; mechanical properties

\section{Introduction}

Heat resistant steels are widely used as structural materials for boilers, main steam pipes, and turbines of power plants [1,2]. In order to improve steam parameters and heat efficiency, researchers have turned their targets to higher-parameter thermal power units above $630{ }^{\circ} \mathrm{C}$ for developing high-capacity ultra-super-critical power plants [3]. At present, the upper limit of the operating temperature of the commercial heat-resistant steel is about $600{ }^{\circ} \mathrm{C}$. Beyond the temperatures, problems in the still, such as thermally unstable microstructure, insufficient durability and insufficient environmental corrosion resistance, need to be considered [4]. Thus, the key factor restricting the construction of a $630{ }^{\circ} \mathrm{C}$ power station is the ability to produce heat-resistant steel in the higher temperature range of $630{ }^{\circ} \mathrm{C}[5,6]$.

In this context, many attempts have been made to overcome this limitation. A martensitic heat-resistant steel with a $9 \mathrm{Cr}-3 \mathrm{~W}-3 \mathrm{Co}$ composition system is pivotal to research and development. MARBN (9Cr-3W-3CoVNbBN) [7-9], SAVE12AD (9Cr-3W-3CoNdVNbBN) [10], NPM (9Cr-3W3CoVNbBN) [11], 9Cr3W (9.5Cr-3.1W-3.2CoVNbBN) [12] and G115 (9Cr-2.8W-3CoCuVNbBN) [13-16] 
steels have been developed. In recent years, many studies were focused on the structures and mechanical properties of G115 steel [13-16], which revealed that G115 steel has excellent structural stability and high-temperature creep properties at $630{ }^{\circ} \mathrm{C}$. The endurance strength of G115 steel at $650{ }^{\circ} \mathrm{C}$ is 1.5 times that of $\mathrm{P} 92$ steel, and its resistance to high-temperature steam oxidation corrosion is better than that of P92 steel [16].

The welding research on heat-resistant steel was mostly concentrated on P91 [17,18] and P92 [19,20] steels. The joints of other steels with a 9Cr-3W-3Co composition system, such as MARBN steel, have also been reported [21,22]. As G115 steel is a newly developed heat-resistant steel, which will be used in the high temperature components; so far researches on the welding of G115 steel were limited. In this study, G115 steel was selected for welding with a heat-resistant steel (CB2), still currently used in the unit. After welding, microstructure similar to that found by casting formed in the weld bead, the heat-affected zone (HAZ) that appears adjacent to the weld line, and residual stress can be produced. To reduce these influences on the joint, post-weld heat treatment (PWHT) was employed. The improvements in the microstructure and mechanical properties of the dissimilar joints of G115 and CB2 steels with PWHT are discussed in detail in this paper.

\section{Materials and Methods}

G115 and CB2 steel blanks, measuring $80 \times 70 \times 2 \mathrm{~mm}$, were machined from as-received plates and utilized as the base metals. The G115 steel plate with dimensions of $200 \times 150 \times 40 \mathrm{~mm}$, which was produced by China BaoWu Steel Group Corporation Limited (Shanghai, China), was in the condition of quenching and high temperature tempering. A filler wire with a diameter of $2.4 \mathrm{~mm}$ was used and its composition was similar to that of G115 steel. The filler wire was made by Atlantic China Welding Consumables INC (Zigong, China). The chemical composition of the substrates and filler are given in Table 1.

Table 1. The chemical composition of the base metals and filler wire (wt.\%).

\begin{tabular}{ccccccccccccccc}
\hline Metals & $\mathbf{C}$ & $\mathbf{C r}$ & $\mathbf{W}$ & $\mathbf{C o}$ & $\mathbf{M o}$ & $\mathbf{C u}$ & $\mathbf{M n}$ & $\mathbf{S i}$ & $\mathbf{N i}$ & $\mathbf{V}$ & $\mathbf{N b}$ & $\mathbf{N}$ & $\mathbf{B}$ & $\mathbf{F e}$ \\
\hline G115 & 0.08 & 8.8 & 2.84 & 3.0 & - & 1.0 & 0.5 & 0.3 & - & 0.2 & 0.06 & 0.008 & 0.014 & Bal. \\
CB2 & 0.11 & 9.18 & - & 0.98 & 1.47 & - & 0.69 & 0.3 & 0.33 & 0.2 & 0.06 & 0.02 & 0.009 & Bal. \\
Filler & 0.088 & 8.95 & 2.8 & 3.01 & - & 0.94 & 0.35 & 0.07 & - & 0.22 & 0.008 & 0.0096 & 0.009 & Bal. \\
\hline
\end{tabular}

A common welding method, tungsten inert gas (TIG) welding, was used to weld G115 and CB2 steels by a TIG welding machine (YC-300WP5HGN, Panasonnic industrial machinery Co., Ltd., Tangshan, China). Based on the results of previous research, the welding current, the wire feed speed and the welding speed were $130 \mathrm{~A}, 0.5 \mathrm{~m} / \mathrm{min}$ and $0.15 \mathrm{~m} / \mathrm{min}$, respectively. The post-welding heat treatment was conducted at 700,730 and $760{ }^{\circ} \mathrm{C}$ for $2 \mathrm{~h}$ in a resistance heating furnace. The temperature of the solid solution of CB2 steel was about $730{ }^{\circ} \mathrm{C}$.

Specimens for metallographic examination were sectioned from the welded joints. Ground and polished cross sections were etched in a solution $\left(5 \mathrm{~g} \mathrm{FeCl}_{3}+15 \mathrm{~mL} \mathrm{HCl}+80 \mathrm{~mL} \mathrm{H}_{2} \mathrm{O}\right)$ to observe the joint microstructure. Microstructural observations were conducted using an optical microscope (OM, DM2000X, Chongqing, China) and a scanning electron microscope (SEM, TESCAN VEGA 3 LMH, Brno, Czech Republic). Morphology and precipitates were analyzed by TEM. Microhardness testing was used to determine the hardness profile of the joint region. The testing was carried out using a load of $4.9 \mathrm{~N}$ on a hardness tester $\left(\mathrm{MH}_{3} \mathrm{~N}\right)$. The hardness testing was performed at a position $1 \mathrm{~mm}$ below the surface, and the distance between the hardness points was about $0.25 \mathrm{~mm}$. Tensile tests were conducted by an electronic tensile test machine (AG-X 50KN, Shimadzu, Kyoto, Japan), where the loading rate was $1 \mathrm{~mm} / \mathrm{min}$. The tensile testing is shown schematically in Figure 1 . Three specimens were tested for each condition. After tensile testing, the fracture surfaces of the samples were observed with SEM. 


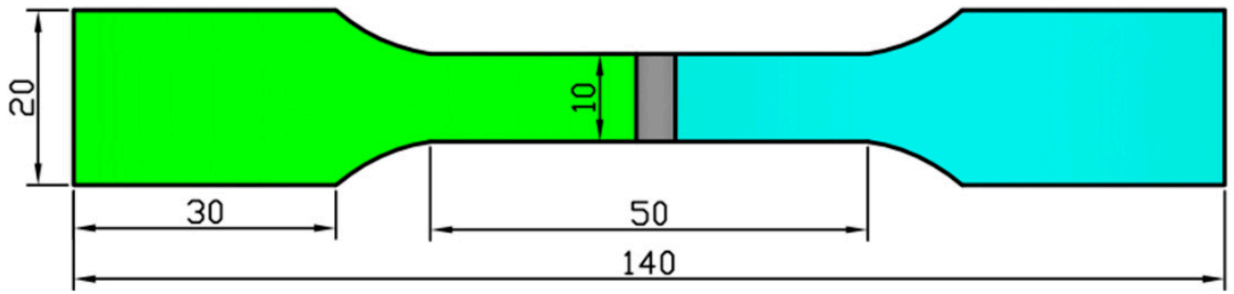

Figure 1. The schematic drawing for tensile testing $(\mathrm{mm})$.

\section{Results and Discussion}

\subsection{Microstructure of the Weld Metal}

Figure 2 exhibits typical weld metal OM and SEM images of specimens prepared without and with PWHT (post-weld heat treatment) at a temperature of $730{ }^{\circ} \mathrm{C}$ after holding for $2 \mathrm{~h}$. Without PWHT, the microstructure of the weld seam was dominated by lath martensite. The boundaries of martensite lath bundles were clearly visible, and the martensite in each lath bundle had relatively uniform directionality. With PWHT, the tempered martensite laths were discontinuous, and the boundaries of the martensite lath bundles became less clear. Fine grain precipitates were found on the martensite laths and the boundaries of the lath bundles; the number of precipitation phases was large and their distribution was dispersed.
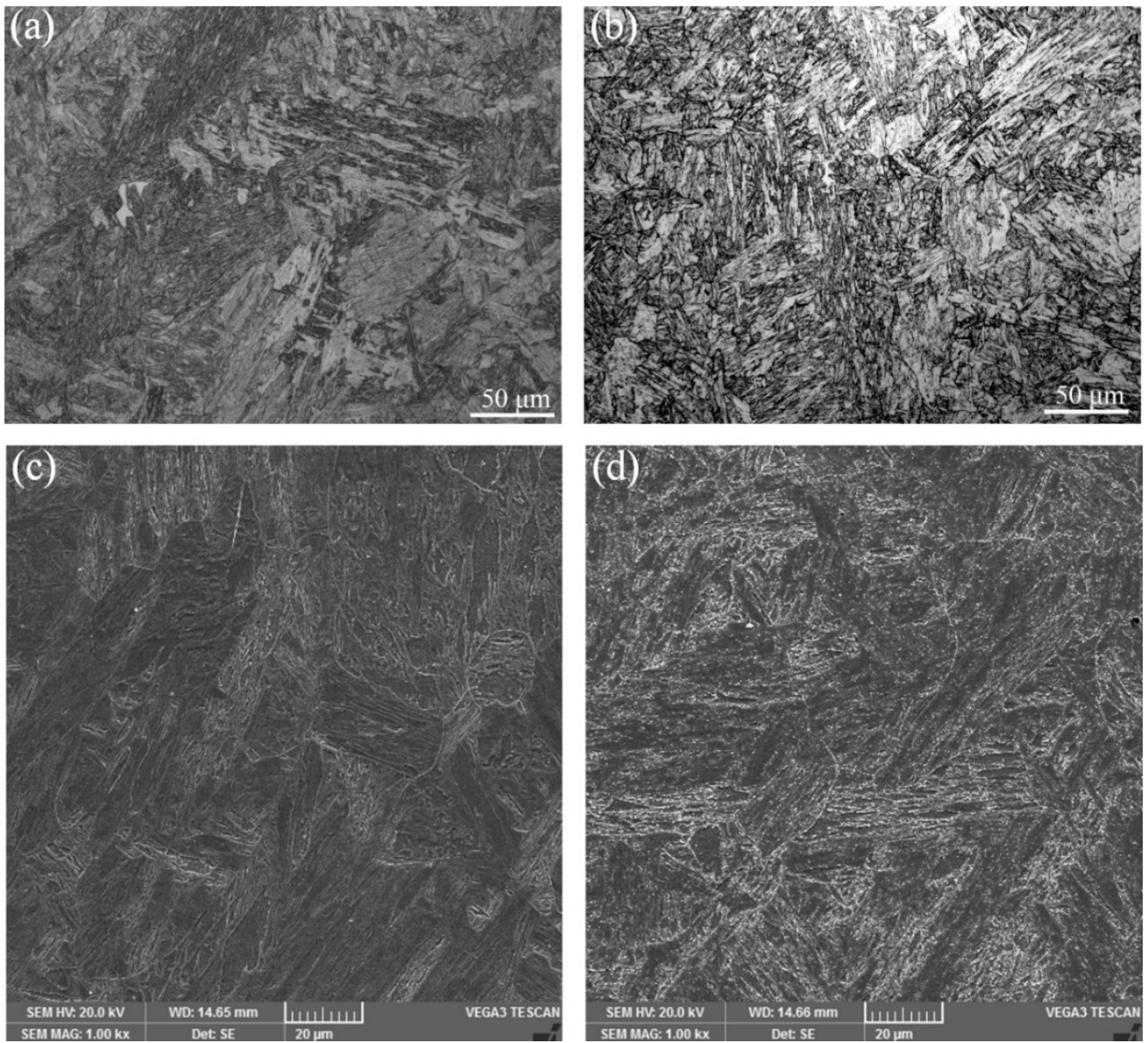

Figure 2. Optical microscope (OM) and scanning electron microscope (SEM) images of typical weld metal specimens: (a), (c) without post-weld heat treatment (PWHT); and (b,d) with PWHT at $730{ }^{\circ} \mathrm{C}$ for $2 \mathrm{~h}$. 
Figures 3 and 4 demonstrate the typical SEM images of HAZ (heat-affected zone) and the base metal of CB2 steel and G115 steel. The results in Figures 3a-c and $4 a-c$ are from as-welded joints, whereas the images in Figures $3 \mathrm{~d}-\mathrm{f}$ and $4 \mathrm{~d}-\mathrm{f}$ are from the joints with PWHT at $730^{\circ} \mathrm{C}$ for $2 \mathrm{~h}$. The microstructure of CB2 steel and G115 steel is shown in Figure 3c,f and Figure 4c,f. Figure 3a,b, Figure 3d-e, Figure 4a,b and Figure $4 \mathrm{~d}$,e show steel that is in the HAZ. The positions for Figure $3 \mathrm{a}, \mathrm{d}$ and Figure $4 \mathrm{a}, \mathrm{d}$ were closer to the weld metal than Figure $3 b$,e and Figure $4 b$,e, respectively. In contrast with Figure $3 b$,e and Figure $4 b$,e, the size of martensite lath bundles shown in Figure $3 a, d$ and Figure $4 a$,d was relatively larger, due to the higher temperature effect of these areas closer to the weld line. There are a few precipitates in the substrate of G115 steel in the joint without PWHT; that is because the as-received condition of the G115 steel is different from the condition of the CB2 steel. As compared with the as-welded joint, many precipitates were observed in the HAZ for the base metal involving CB2 and G115 steel after PWHT at $730{ }^{\circ} \mathrm{C}$ for $2 \mathrm{~h}$.
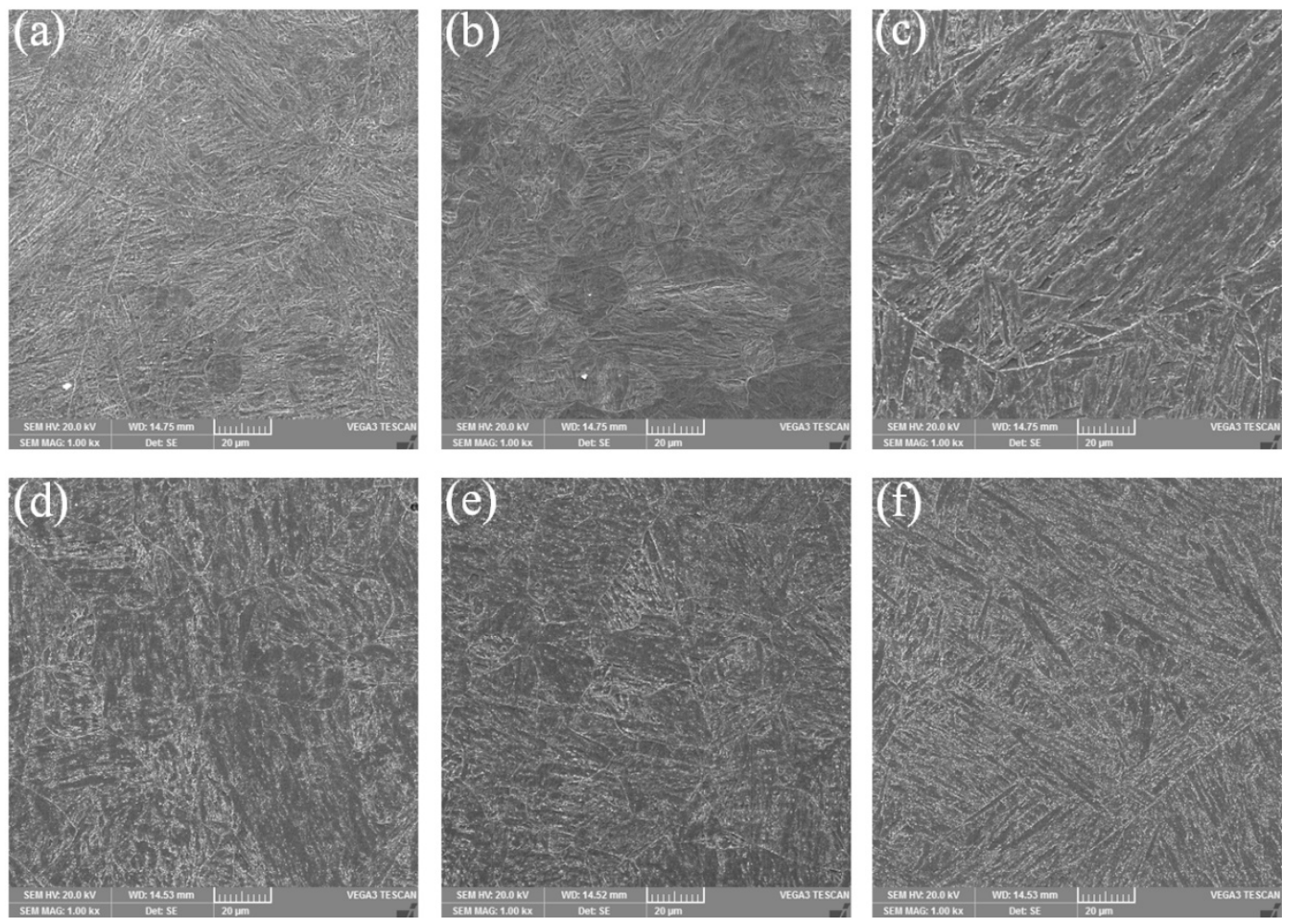

Figure 3. Typical SEM images of the heat-affected zone (HAZ) (a,b), (d,e) and base metal (c), (f) of CB2 steel: (a)-(c) without PWHT and (d)-(f) with PWHT at $730^{\circ} \mathrm{C}$ for $2 \mathrm{~h}$.

Figure 5 shows typical TEM (transmission electron microscope) images of the weld metal in the joints produced without PWHT. From Figure 5, the matrix phase of the weldment was martensite, and the width of the martensite lath was approximately several hundred nanometers. The distribution of the lath martensite with a certain length was regular and directional. The quenched martensite was formed by shearing and resulted in a high defect density. A large number of dislocations and dislocation tangles were detected on and between the martensite laths. These dislocations were unevenly distributed, and the dislocation cells of the cellular substructure might be formed in some high-density dislocation regions. 

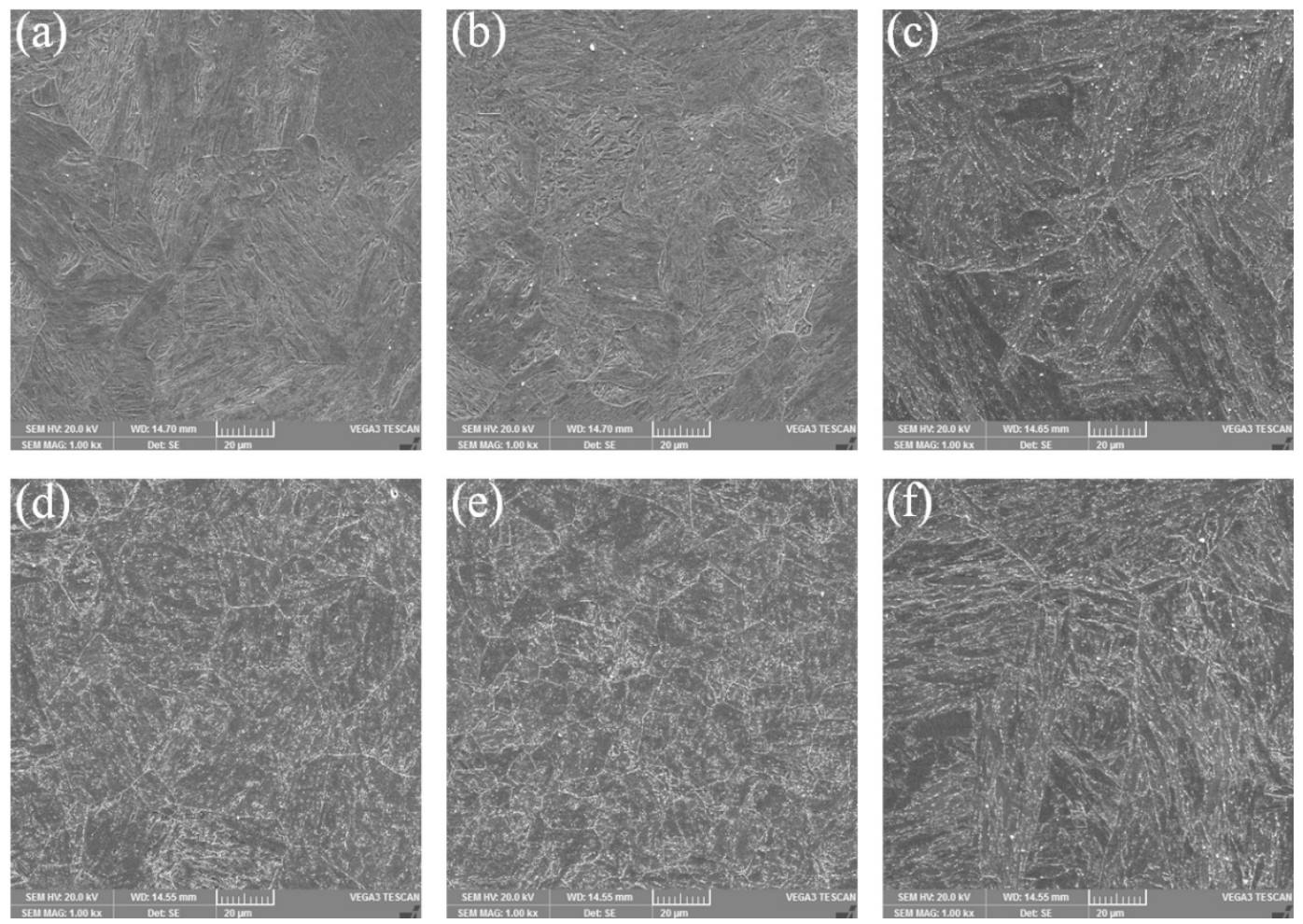

Figure 4. Typical SEM images of HAZ $(\mathbf{a}, \mathbf{b}),(\mathbf{d}, \mathbf{e})$ and base metal (c), (f) of G115 steel: (a)-(c) without PWHT and (d)-(f) with PWHT at $730{ }^{\circ} \mathrm{C}$ for $2 \mathrm{~h}$.
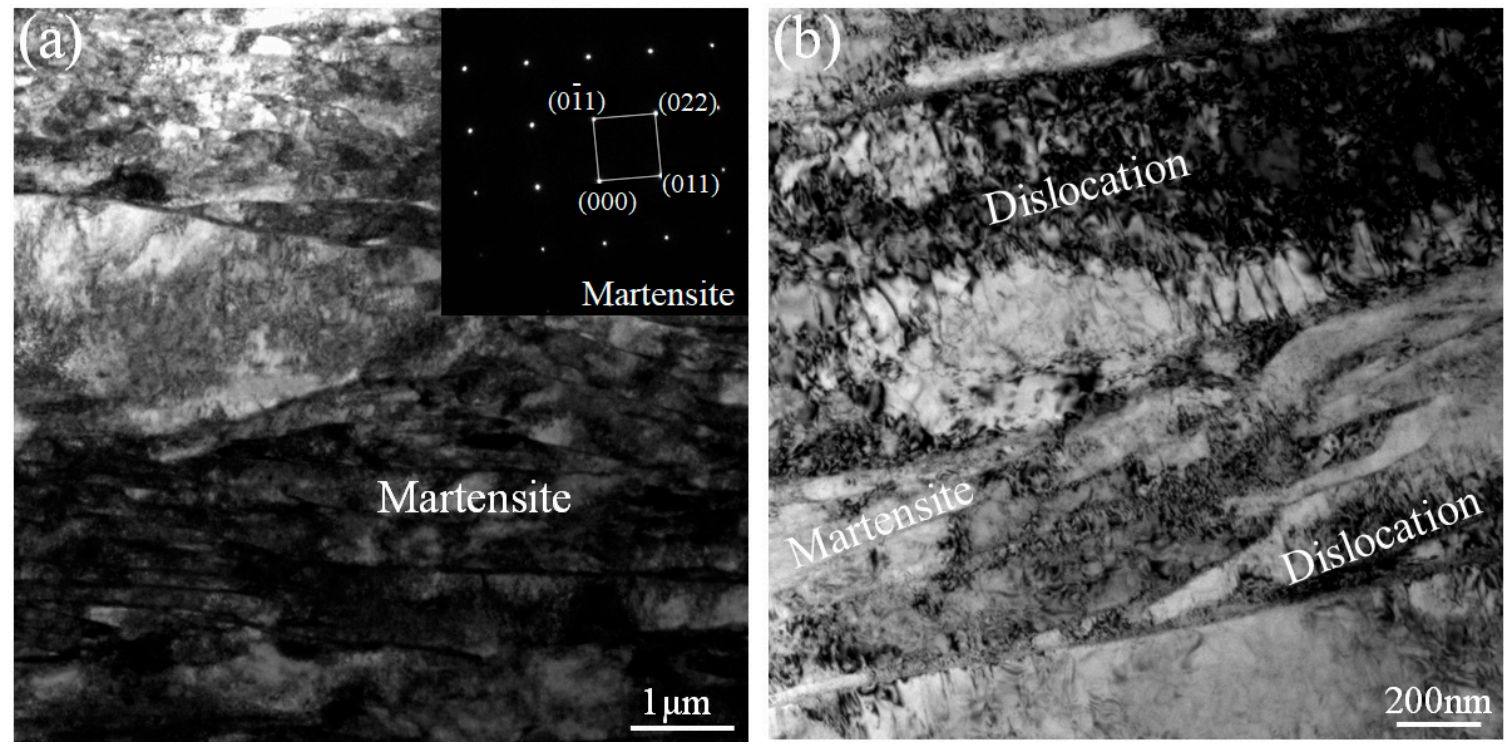

Figure 5. Typical weld metal TEM analysis of the joints produced without PWHT: (a) TEM images and diffraction patterns of martensite, and (b) dislocation.

Figure 6 illustrates typical weld metal TEM images of the joints obtained with PWHT at $730{ }^{\circ} \mathrm{C}$ for $2 \mathrm{~h}$. From Figure 3, the directionality and length of the martensite laths were clearly reduced and shortened after PWHT, which can be explained by the following three reasons: (1) Firstly, the long laths of quenched martensite are decomposed, owing to the effect of the high temperature. (2) Secondly, some martensite phases undergo recovery and recrystallization processes, and then the equiaxed crystals with low dislocation density are transformed from the lath crystals. (3) Thirdly, sub-grains are formed from remaining dislocations, through multilateralization and then gradually grow up when 
undergoing higher temperature for an extended long time. The dislocation density was decreased significantly, which can be attributed to the reduction and disappearance of dislocations and dislocation cells in the recovery process during PWHT. The carbides were identified as $\mathrm{M}_{23} \mathrm{C}_{6}$ phase by the diffraction patterns. Many carbide particle phases were formed on the grains and grain boundaries. The precipitate size ranged from approximately several nanometers to tens of nanometers, and the size of very few carbides was approximately hundreds of nanometers.
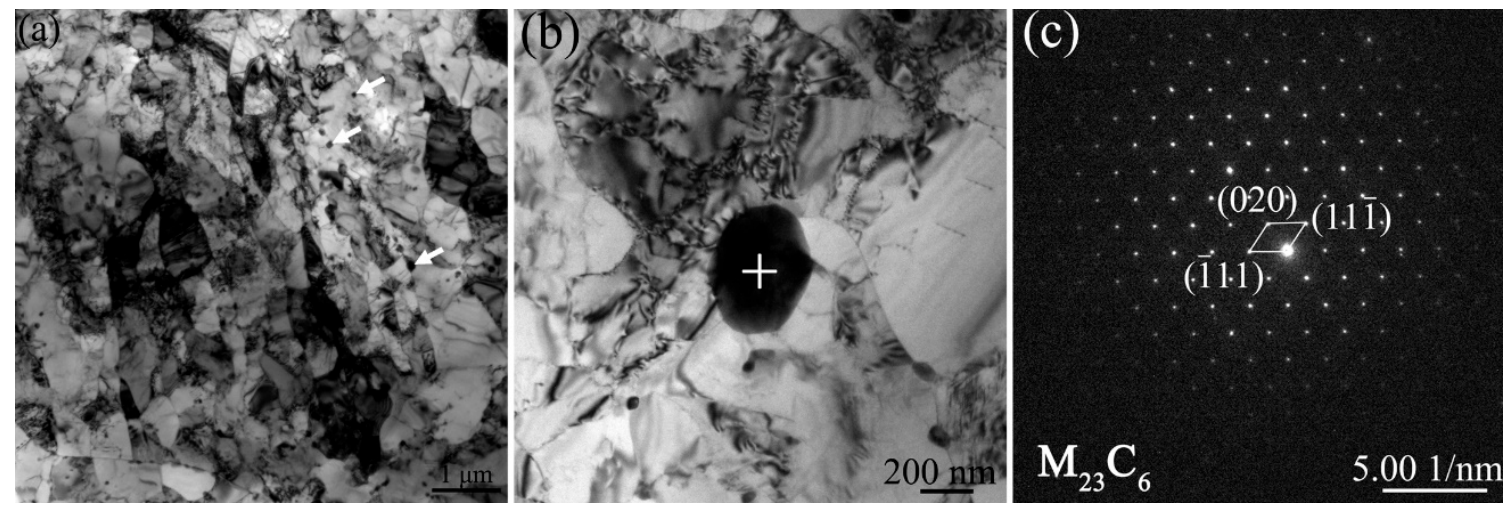

Figure 6. Typical weld metal TEM analysis of the joints obtained with PWHT at $730{ }^{\circ} \mathrm{C}$ for $2 \mathrm{~h}$ : (a) TEM images, (b) precipitates images, and (c) diffraction patterns of precipitate. The white arrows highlight the precipitates.

\subsection{Microhardness of the Joint}

Figure 7 displays the variation of microhardness in the joint region without and with PWHT. For the as-welded joint, the microhardness of the weld metal, whose average value is about $400 \mathrm{HV}$, is significantly higher than that of the G115 steel and CB2 steel. This might be interpreted in the following four aspects: (1) Firstly, the quenched martensite transformed by rapid cooling has higher microhardness, which results in transformation hardening in the weld zone. (2) Secondly, there are no carbide precipitates in the quenched martensite matrix, and almost all carbon atoms are dissolved into the matrix in a supersaturated form. This can lead to solid solution hardening in the weld zone. (3) Thirdly, the residual stress produced by welding and stored in the weldment makes the measured microhardness values higher. (4) Finally, a large number of dislocations (Figure 5b) are produced in the rapid cooling process and during the quenched martensite formation. This might cause dislocation hardening in the weld seam. The microhardness values of the base metal areas were higher than those of the center area, because the above-mentioned four hardening effects are greater at the faster cooling rate. The microhardness of the G115 steel was similar to that of the CB2 steel, and its value was approximately $250 \mathrm{HV}$. By comparing the two cases of without and with PWHT, an obvious change in the microhardness profile is that the microhardness of the weld seam was sharply reduced to 265-290 HV after PWHT. The transformation of tempered martensite from quenched martensite, the reduction of the solid solution carbon content in martensite, the elimination of the remaining stress and the decrease and disappearance of dislocation density during PWHT can make the microhardness of the weldment notably low. As the PWHT temperature increased, the microhardness of the G115 steel side did not change significantly, which indicates that the G115 steel has good high temperature stability. However, the microhardness of the weldment and CB2 steel side was slightly reduced especially at $760{ }^{\circ} \mathrm{C}$. The further coarsening of grains at the higher temperature may be responsible for the decrease in microhardness. 


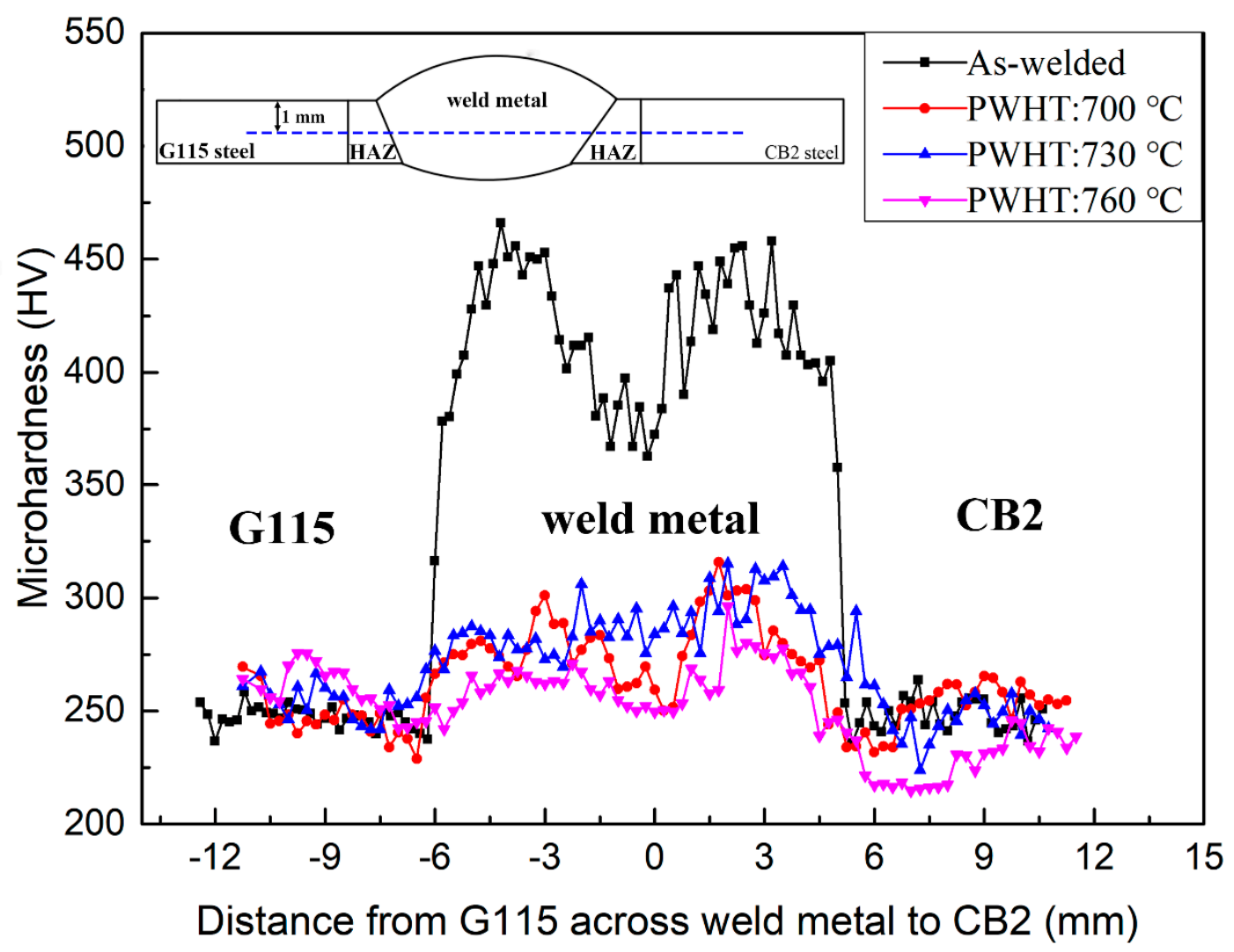

Figure 7. The microhardness profiles of the joint of G115 steel and CB2 steel without and with PWHT.

\subsection{Tensile Strength of the Joint}

Figure 8 presents the tensile strengths of the joints without and with PWHT. The tensile strength of the joint without PWHT was about $630 \mathrm{MPa}$, and the fracture during tensile testing was located in the weld seam. Due to the large amount of fine carbides with dispersed distribution (Figure 6), the tensile strength values of the joints that underwent PWHT were notedly larger than those without PWHT, and the failure during tensile testing took place in the base metal of CB2, which indicates that the thermal strength of CB2 is lower than that of G115. As the PWHT temperature increased from 700 to $730^{\circ} \mathrm{C}$, the joint strength improved markedly, whereas the joint strength clearly decreased by further increasing the PWHT temperature from 730 to $760^{\circ} \mathrm{C}$. The reduction in the properties including microhardness and tensile strength of $\mathrm{CB} 2$ steel at $760^{\circ} \mathrm{C}$ might be because the temperature was higher than the solid solution temperature of CB2 steel. The maximum strength of the joint that was reached was $694 \mathrm{MPa}$ at the PWHT temperature of $730{ }^{\circ} \mathrm{C}$, which was approximately $94 \%$ of the tensile strength of the base metal (Table 2).

Table 3 shows the yield strength and elongation to failure of the welded joints without and with PWHT. The yield strength values of the joints with PWHT are much larger than those without PWHT. The yield stress exhibits a change that firstly increases and then decreases as the temperature of PWHT enhances, which was similar to the change in the tensile strength. The maximum yield strength obtained with PWHT at $730{ }^{\circ} \mathrm{C}$ was higher than that of the joint without PWHT by about $159 \mathrm{MPa}$. The ductility of the joint increased significantly after PWHT, and the elongation values of the joints with PWHT were an order of magnitude larger than those without PWHT. 


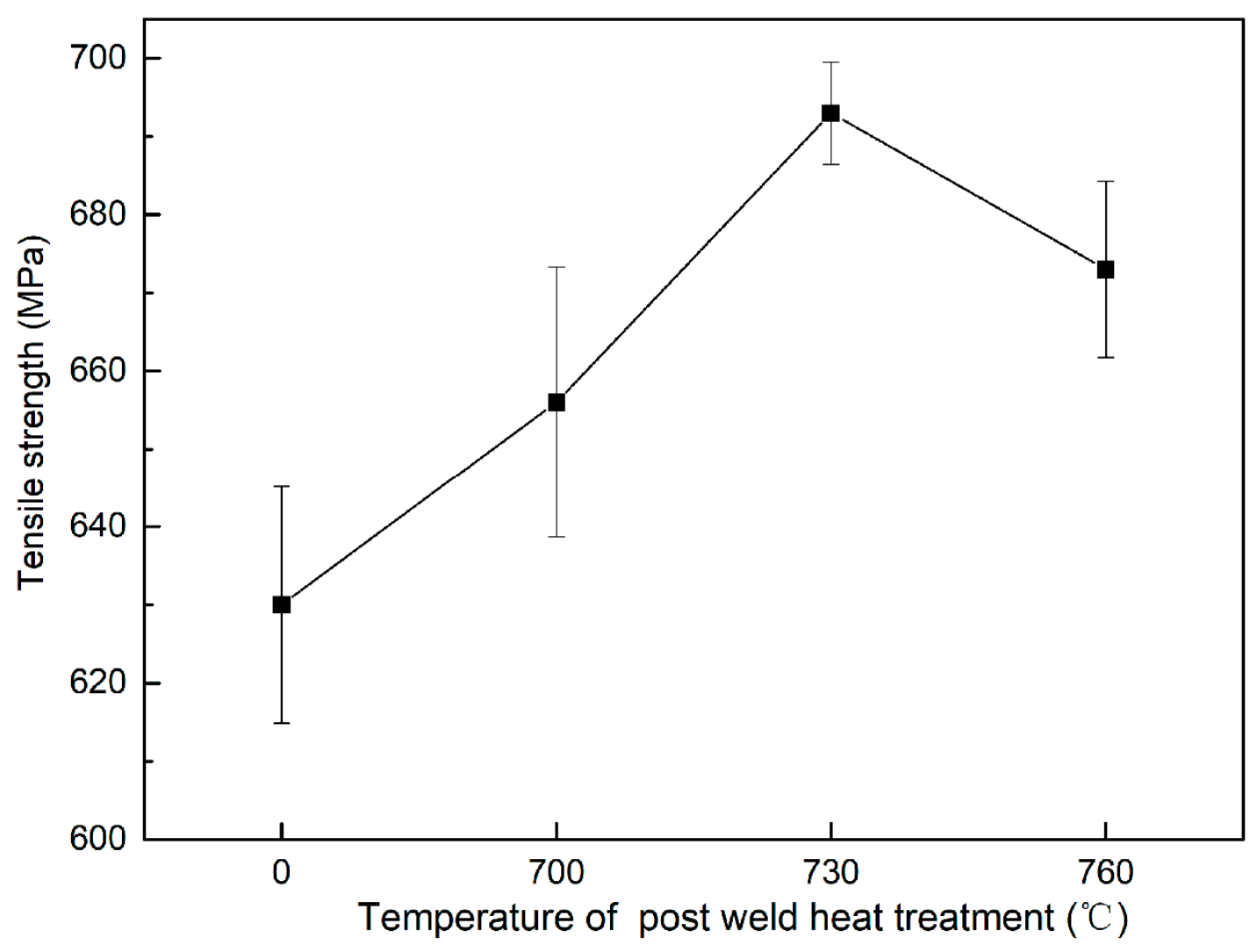

Figure 8. Tensile strengths of the joints of G115 steel and CB2 steel without and with PWHT.

Table 2. Elongation, yield strength and tensile strength of the base metals.

\begin{tabular}{ccccc}
\hline & $\begin{array}{c}\text { As-Received } \\
\text { G115 }\end{array}$ & $\begin{array}{c}\text { As-Received } \\
\text { CB2 }\end{array}$ & $\begin{array}{c}\text { G115 at 730 }{ }^{\circ} \mathbf{C} \\
\text { for 2 h }\end{array}$ & $\begin{array}{c}\text { CB2 at 730 }{ }^{\circ} \mathbf{C} \\
\text { for 2 h }\end{array}$ \\
\hline Elongation (\%) & 8.92 & 6.14 & 10.6 & 7.79 \\
Yield strength (MPa) & 641 & 623 & 621 & 614 \\
Tensile strength (MPa) & 749 & 746 & 745 & 740 \\
\hline
\end{tabular}

Table 3. Elongation and yield strength of the welded joints without and with PWHT.

\begin{tabular}{ccccc}
\hline & $\begin{array}{c}\text { As-Weld } \\
\text { Joint }\end{array}$ & $\begin{array}{c}\text { PWHT at } 700{ }^{\circ} \mathbf{C} \\
\text { for } \mathbf{2 ~ h}\end{array}$ & $\begin{array}{c}\text { PWHT at } 730{ }^{\circ} \mathbf{C} \\
\text { for } \mathbf{~ h ~}\end{array}$ & $\begin{array}{c}\text { PWHT at } 760{ }^{\circ} \mathbf{C} \\
\text { for } \mathbf{~ h ~ h ~}\end{array}$ \\
\hline Elongation $(\%)$ & 0.58 & 6.66 & 6.69 & 7.12 \\
Yield strength (MPa) & 410 & 547 & 569 & 539 \\
\hline
\end{tabular}

\subsection{Fracture Characteristics}

Figure 9 represents the fracture surface images of the joints without and with PWHT of $730{ }^{\circ} \mathrm{C}$. The fracture of the as-welded joint occurred in the weldment; the failed surface contained cleavage fracture characteristics and it is considered to be a mainly brittle fracture. In all cases investigated for PWHT, the weld seam was strengthened and CB2 steel became a weak part, causing fractures that occurred in the CB2 side. The post fracture microstructures of the joints were similar and there were many dimples on the fracture surface. The results indicate that the PWHT process improved the microstructure and mechanical properties of the weldment, thereby avoiding brittle fracture at the weld. 

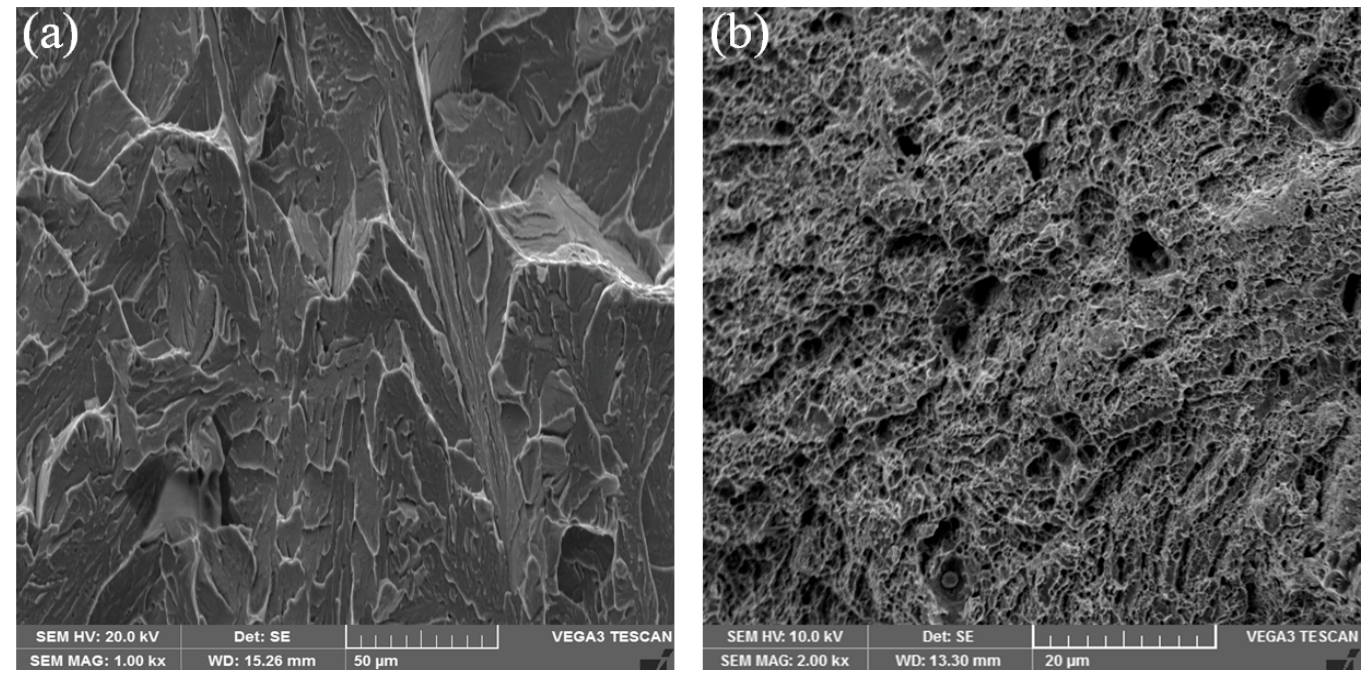

Figure 9. Typical fracture surface SEM images of the joints: (a) without PWHT and (b) with PWHT, at $730{ }^{\circ} \mathrm{C}$ for $2 \mathrm{~h}$.

\section{Conclusions}

In this paper, the microstructures and mechanical properties of the weldment between G115 and CB2 steels without and with PWHT were studied. The related conclusions can be drawn as follows:

(1) Without PWHT, the weld seam was mainly composed of the quenched martensite with a lath thickness of approximately several hundred nanometers Many dislocations and dislocation tangles were found on and between the martensite laths. With PWHT, the tempered martensite was transformed from the quenched martensite and the number of dislocations was drastically reduced. In addition, $\mathrm{M}_{23} \mathrm{C}_{6}$ secondary-phases with the size of approximately several nanometers to tens of nanometers were dispersedly distributed on the grains and grain boundaries.

(2) Without PWHT, the average microhardness of the weldment ( $400 \mathrm{HV})$ was evidently larger than that of the G115 steel and CB2 steel ( $250 \mathrm{HV})$. With PWHT, the microhardness of the weldment decreased to $265-290 \mathrm{HV}$ and the microhardness of CB2 steel was slightly reduced at $760{ }^{\circ} \mathrm{C}$ for PWHT.

(3) Without PWHT, the tensile strength of the joint was about $630 \mathrm{MPa}$, and the fracture with mainly cleavage fracture characteristics occurred in the weld seam. With PWHT, the joint strength increased significantly and reached up to a maximum value $(694 \mathrm{MPa})$ at $730^{\circ} \mathrm{C}$, which might result from many dispersed precipitates, and the fracture with many dimples was located in the base metal of CB2 steel.

Author Contributions: J.X. (Jiankun Xiong), X.Y., J.Y., L.Y., and J.X. (Jian Xu) formulated the original problem, designed the study, developed the methodology, and wrote the manuscript. J.X. (Jiankun Xiong), T.L., X.Y., G.M. and J.X. (Jian $\mathrm{Xu}$ ) performed the welding, testing, characterization and collected data. J.X. (Jiankun Xiong) and G.M. controlled the materials selection. J.X. (Jiankun Xiong) and X.Y. provided guidance and interpretation of data. All authors have read and agreed to the published version of the manuscript.

Funding: This work was financially supported by the Sichuan Deyang Open University-City Cooperative Technology Research and Development Project (Project No.: 2018CKJ004) and the Sichuan Deyang Industry-University-Research Cooperation Technology R\&D Project (Project No.: 2019CK094). This research was also supported by the fund of Sate Key Laboratory of Long-life High Temperature Materials (Project No.: DTCC28EE190934).

Conflicts of Interest: The authors declare no conflict of interest.

\section{References}

1. Fedoseeva, A.; Dudova, N.; Kaibyshev, R.; Belyakov, A. Effect of tungsten on creep behavior of $9 \% \mathrm{Cr}-3 \% \mathrm{Co}$ martensitic steels. Metals 2017, 7, 573. [CrossRef] 
2. Kaybyshev, R.O.; Skorobogatykh, V.N.; Shchenkova, I.A. New martensitic steels for fossil power plant: Creep resistance. Phys. Met. Metallogr. 2010, 109, 186-200. [CrossRef]

3. Wang, X.; Wang, X.; Luo, B.; Hu, X.; Yuan, T. Creep degradation assessment in 9\%Cr heat-resistant steel welded joints using ultrasonic methods. Results Phys. 2019, 12, 307-320. [CrossRef]

4. Zinkle, S.J.; Was, G.S. Materials challenges in nuclear energy. Acta Mater. 2013, 61, 735-758. [CrossRef]

5. Rojas, D.; Garcia, J.; Prat, O.; Sauthoff, G.; Kaysser-Pyzalla, A.R. 9\%Cr heat resistant steels: Alloy design, microstructure evolution and creep response at $650^{\circ} \mathrm{C}$. Mater. Sci. Eng. A 2011, 528, 5164-5176. [CrossRef]

6. Wang, H.; Yan, W.; Zwaag, S.V.; Shi, Q.; Wang, W.; Yang, K.; Shan, Y. On the $650{ }^{\circ} \mathrm{C}$ thermostability of $9 \mathrm{e} 12 \mathrm{Cr}$ heat resistant steels containing different precipitates. Acta Mater. 2017, 134, 143-154. [CrossRef]

7. Abe, F. New Martensitic Steels. In Materials for Ultra-Supercritical and Advanced Untra-Supercritical Power Plants; Gianfrancesco, A.D., Ed.; Woodhead Publishing: Cambrige, UK, 2017; pp. 323-374.

8. Abe, F. Development of Creep-Resistant Steels and Alloys for Use in Power Plants. In Structural Alloys in Power Plants; Shirzadi, A., Jackson, S., Eds.; Woodhead Publishing: Cambridge, UK, 2014; pp. 250-293.

9. Abstossa, K.G.; Schmigallab, S.; Schultzeb, S.; Mayr, P. Microstructural changes during creep and aging of a heat resistant MARBN steel and their effect on the electrochemical behaviour. Mater. Sci. Eng. A 2019, 743, 233-242. [CrossRef]

10. Iseda, A.; Yoshizawa, M.; Okada, H.; Hamaguchi, T.; Hirata, H.; Joutoku, K.; Ono, T.; Tanaka, K. Development of 9Cr ferritic steel tube and pipe SAVE12AD for advanced power boilers. Therm. Nucl. Power Gener. Conv. Collect. Works 2016, 12, 49-55.

11. Hollner, S.; Piozin, E.; Mayr, P.; Caës, C.; Tournié, I.; Pineau, A.; Fournier, B. Characterization of a boron alloyed $9 \mathrm{Cr} 3 \mathrm{~W} 3 \mathrm{CoVNbBN}$ steel and further improvement of its high-temperature mechanical properties by thermomechanical treatments. J. Nucl. Mater. 2013, 441, 15-23. [CrossRef]

12. Fedoseeva, A.; Dudova, N.; Kaibyshev, R. Creep behavior and microstructure of a 9Cr-3Co-3W martensitic steel. J. Mater. Sci. 2017, 52, 2974-2988. [CrossRef]

13. Xiao, B.; Xu, L.; Zhao, L.; Jing, H.; Han, Y.; Zhang, Y. Creep properties, creep deformation behavior, and microstructural evolution of $9 \mathrm{Cr}-3 \mathrm{~W}-3 \mathrm{Co}-1 \mathrm{CuVNbB}$ martensite ferritic steel. Mater. Sci. Eng. A 2018, 711, 434-447. [CrossRef]

14. Liu, Z.; Liu, Z.; Wang, X.; Chen, Z. Investigation of the microstructure and strength in G115 steel with the different concentration of tungsten during creep test. Mater. Charact. 2019, 149, 95-104. [CrossRef]

15. Xiao, B.; Xu, L.; Cayronc, C.; Xue, J.; Sha, G.; Logé, R. Solute-dislocation interactions and creep-enhanced Cu precipitation in a novel ferritic-martensitic steel. Acta Mater. 2020, 195, 199-208. [CrossRef]

16. Yu, Y.; Liu, Z.; Zhang, C.; Fan, Z.; Chen, Z.; Bao, H.; Chen, H.; Yang, Z. Correlation of creep fracture lifetime with microstructure evolution and cavity behaviors in G115 martensitic heat-resistant steel. Mater. Sci. Eng. A 2020, 788, 139468. [CrossRef]

17. Silva, F.J.G.; Pinho, A.P.; Pereira, A.B.; Paiva, O.C. Evaluation of welded joints in P91 steel under different heat-treatment conditions. Metals 2020, 10, 99. [CrossRef]

18. Wang, Y.; Li, L.; Kannan, R. Transition from type IV to type I cracking in heat-treated grade 91 steel weldments. Mater. Sci. Eng. A 2018, 714, 1-13. [CrossRef]

19. Wang, X.; Pan, Q.; Liu, Z.; Zeng, H.; Tao, Y. Creep rupture behaviour of P92 steel weldment. Eng. Fail. Anal. 2011, 18, 186-191.

20. Sklenička, V.; Kuchařová, K.; Svobodová, M.; Kvapilová, M.; Král, P.; Horváth, L. Creep properties in similar weld joint of a thick-walled P92 steel pipe. Mater. Charact. 2016, 119, 1-12. [CrossRef]

21. Mayr, P.; Martín, F.M.; Albu, M.; Cerjak, H. Correlation of creep strength and microstructural evolution of a boron alloyed $9 \mathrm{Cr} 3 \mathrm{~W} 3 \mathrm{CoVNb}$ steel in as-received and welded condition. Mater. High Temp. 2014, 27, 67-72. [CrossRef]

22. Matsunaga, T.; Hongo, H.; Tabuchi, M.; Sahara, R. Suppression of grain refinement in heat-affected zone of 9Cr-3W-3Co-VNb steels. Mater. Sci. Eng. A 2016, 655, 168-174. [CrossRef]

(C) 2020 by the authors. Licensee MDPI, Basel, Switzerland. This article is an open access article distributed under the terms and conditions of the Creative Commons Attribution (CC BY) license (http://creativecommons.org/licenses/by/4.0/). 